\title{
影関節円板㭗成コラーゲンの生化学的分析
}

鹿纱健问

\section{Biochemical studies on collagen in temporomandibular joint discs}

\author{
Kenji Kashima
}

\begin{abstract}
Bur hemical reports on temporomandibular joint (TMJ) composition at physiological and pathological conditions have been rather scarer when compared to those of morphological studies. The present investigation was intended to characterize cross-links and types of collagen in T'MJ disc, which is thought to be one of the most important clements in maintaining the structure, strength and smooth function of the joint.

Amino acid analyses of human and porcine TMJ discs ascertained that collagen was the majority among the tissue components. Reducible cross-links were analyzed by radiochromatography after reducing with $\left[{ }^{3} \mathrm{H}\right]-\mathrm{NaBH}_{4}$ and characteristic patterns were obtained in reducible cross-links of porcine and human samples, respectively. In porcine discs, relatively large amounts of reducible cross-links such as dihydroxylysinonorleucine, hydroxylysinonorleucine and histidinohydroxymerodesmosine were detected. Age-related decrease in all of the reducible cross-links was observed. Human discs contained less amount of reducible crosslinks than porcine samples. However, one reducible component related to hexitollysine, which is desig-nated $\mathrm{Al}$, was abundant in human discs.

Non-reducible cross-links, pyridinoline and histidinoalanine in TMJ discs, were determined with an amino acid analyzer after hydrolysis. The former was detected in all tissue samples examined and was found to decrease with aging. The latter, which is considered to be a cross-link between collagen and related proteins, was detected in aged samples especially in perforated disc but not found in younger samples.

Collagen type analysis by gel electrohoresis revealed that both procine and human TMJ discs consisted almost exclusively of type I, however, porcine sample contained a trace amount of type III collagen.
\end{abstract}

Key words: TMJ disc, collagen, cross-link

緒訔

顎関節疾患には，外傷をはじめ炎症，腫瘍などがあ りななかても顎関節症は最近の社会環境の複雑化に伴い 增加の傾向にある ${ }^{1)}$ 本症は，その多様な臨床症状から

東京医科檕科大学莯学部第 1 口腔外科学教室 （主任・指導：塩田重利教授）

The First Department of Oral Surgery, Faculty of Dentistry, Tokyo Medical and Dental University (Chief and Director: Shigetoshi Shioda) 受付日：昭和62年11月13日
種々の病名が用いられてきたが，柴田ら2)は最近，䫚関 節症を大きく三つの症型に分類している。すなわち， (1) 咀弾筋に障害が限局寸るもの，(2) 颚関節部軟組織 に障害が及ぶもの，(3) 顎閶節部硬組織に障害が及ぶも の,の 3 症型である。このうち, 買関節部軟組織の障害 は，早期に関節円板に病的变化が現れることが多いと述 べている.

Scapino $^{3)}$ は，正常䫛関節および関節円板に異常が認 められた症例の頞関節組織所見について観察し, コラー ゲン線䧽の配列，走行について詳細に検索している。 た，最近 Isacsson 54) は強い疼痛を伴ら䫇関節症患者 の円板切除を行い，その手術標本の組織学的検討を加え 
$\tau$, 円板後方付着部の connective tissue hyalinization を報告している.

このように、関節円板の組船之病態に阙する阫宛は, 現在まで主として形想学的な方法によるものが多く、こ の組織を生化学的に取り扱った研然はあまり行いけてい ない.

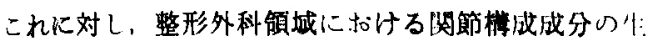
化学的研究は古くから行われ，阙節軟骨のクリコサミ， グリカンに関して、特に早くからその一次梏造や代㴬過 程が研究されてきだ，次いて，骨，㳄骨，椎们恔など の主要有機成分であるコラーゲンに閣して，价化学研究

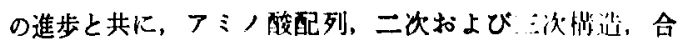

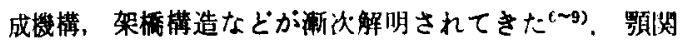
節に関して，特に阅節円板に関与る生化学的研究は著者

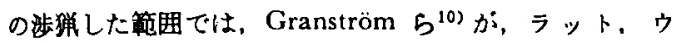
サギ，イヌ、サルの関節円板中のグリコサミノがリカン を調べ，その結果ヒアルロン酸とデルマタン硫酸が存在 し，その割合は後者の方が多いと報告している，また， Hirshmann $5^{111}$ は，ウン胎見の関節円板を梌索したと ころ，その構成コラーダンが型技よび滑膜由来と考之 られるごく少量の正型から成ると報告しているにすぎな い、したがって，関節円板を構成するコラーダンについ ての分子レベルでの性格やそれらと病態との関連は，現 在まで明らかにされていないのが見状である.

1969年に軟骨での II 型が確認されて以来 ${ }^{12), ~ コ ラ ー ケ ゙ ~}$ ンは次々に遺伝子的に異なった分子種の存在が明らかに されてきて括り，現在主なものだけでI 型からV型まで の 5 種類が，さらに最近ではX型まで記载がなされてい

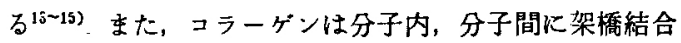
を形成することによって十分な機械的，化学的安定性を 獲得するといわれ，現在約10種の架橋結合が知られてお り,これらは還元性, 非還元性架橋に大別される。 こラ ーゲンのこのような型や架橋結合は，各組織においてて ぼ一定の特晸を持っており，さらに加踰によっても特徽 的な変化が進行するといわれている(18).これらのことか ら本研究では関節円板の構成成分の主体であるコラーゲ ンに着目し，その生化学的性状を明らかにするため，ヒ トおよびブタの関節円板を用いて型および架橋結合分析 を行った．また，病的状態の七ト関節円板についても分 析したのであわせて報告する.

\section{実 験 材 料}

ヒト蝢関節円板は剖検および手術摘出物から得たもの を試料とした，年路は26歳〜85歳（平均58.9歳）の男性 9 例，女性 4 例であり，生前，術前飞額関節疾患の訴え がないことを確認した。 また，七トに類似した咬合様式 を有するブタの生後約 6 か月就よび約 4 年の顎関節を屠 殺場より入手し，関節円板を採取した。

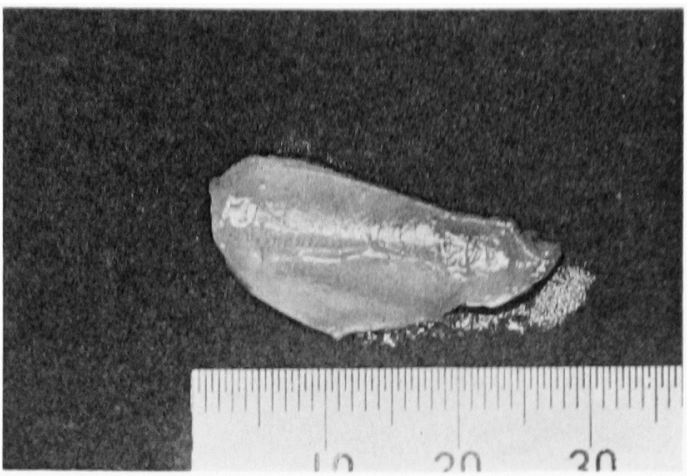

图 1 a 七上闺節円板中央部（50旅，男性）

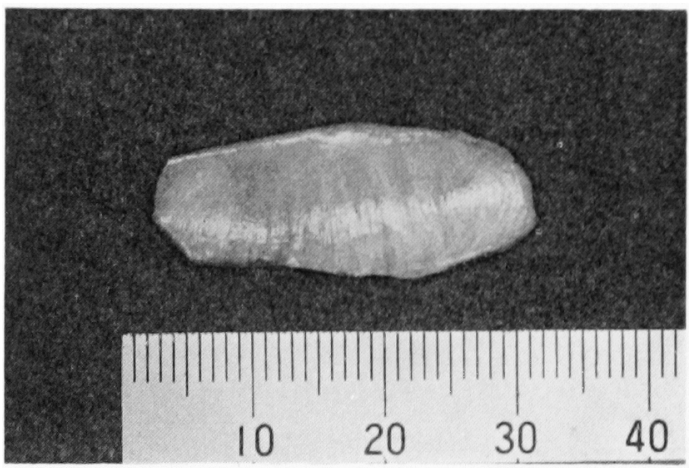

図 $1 \mathbf{b}>$ タ関節円板中央部（生後 6 か月）

採取したこれらの関節円板は頼関節円板に関する三沢 の分類 ${ }^{17}$ に準し，関節円板のほぼ中央部で機能的関節面 に相当する部位，すなから円板関節面を周囲部分から切 り分け試料とした（図1 $\mathbf{a}, \mathbf{b}$ )。これはその周围の領域 に存在する血管由来ュラーゲンの混入を排除するためで ある。

ヒト関節円板では，2 例に穿孔が観察された（图 $2 \mathbf{a}$, b). 75 歳の症例は円板関節面外側に小穿孔があり，穿 孔部周囲をさらにその周囲組織と分けて採取し，また， 50歳の症例では円板全体に及ぶ大穿孔がみられ，わすか に残存していたけ板組織を採取し、それぞれ試料とし た.

生後約 6 か月よび約 4 年のブタ皮膚を採取し，対照 として用いた。

得られた試料は $0.9 \% \mathrm{NaCl} / 0.05 \mathrm{M}$ Tris- $\mathrm{HCl}(\mathrm{pH}$ 7.4）にて洗浄後，分析まで $-20^{\circ} \mathrm{C}$ にて保存した。

\section{実 験 方 法}

\section{1. 水分含量の測定}

$0.9 \% \mathrm{NaCl} / 0.05 \mathrm{M}$ Tris- $\mathrm{HCl}(\mathrm{pH} \mathrm{7.4})$ で洗浄した 試料より，濾紙にて余剰の水分を除去し，この涷結乾燥 


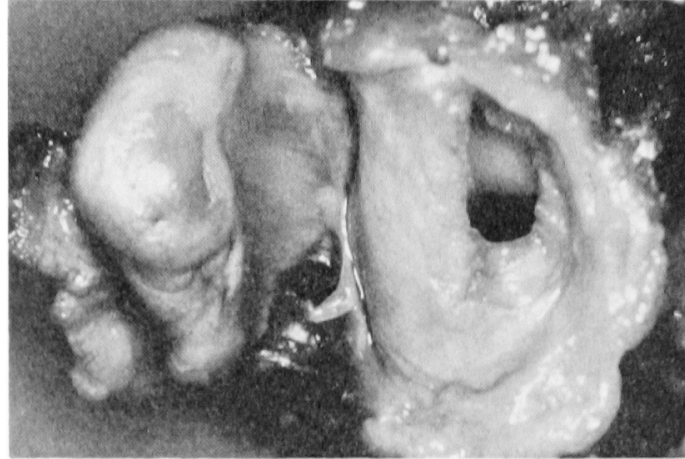

因 $2 \mathbf{a}$ 四節円板第孔例(75多，女件）

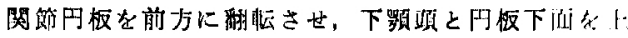
方よりみた

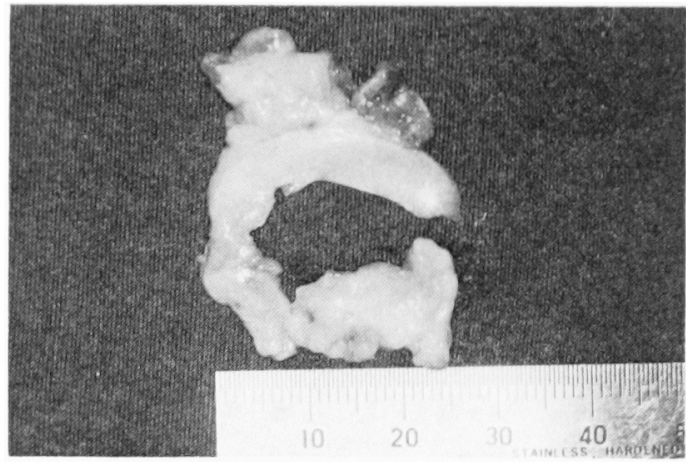

図 2 b 関節円板大呀孔例（50篎，男性） 本症例では，穿孔部周围の残存円板組繶を报して 試料とした

前後の重量がら水分含量を測定した。

2. コラーゲンの抽出法

以下の操作は特に記載がない限り4‘Cで行った。

Kuboki ら ${ }^{18)}$ の方法に従い，試料を細分割し，さらに 液体窒素中で粉砕して 3 種のプロテアーゼ阻害剤（100 $\mathrm{mM}$ 6-アミノ-n-カプロン酸, $5 \mathrm{mM}$ 塩酸ベンザミジン, $1 \mathrm{mM}$ ベンジルスルホニルフルオライド) を含む $1 \mathrm{M}$ $\mathrm{NaCl} / 0.05$ Tris- $\mathrm{HCl}$ 綏衝液（pH 7.4）にて 48 時間, 3 回抽出を行った。この後遠心 $(30,000 \times \mathrm{g}, 30$ 分)に て分離し，可溶性と不溶性画分とに分けた。おのおの冷 蒸留水に対して透析脱塩後, 凍結乾燥して中性塩可溶性 画分および中性塩不溶性画分とした。

扣の拉のの画分の一部は後述するてミ，酸分析を行 い,コラーゲン含量を算出した.

\section{3. 了ミノ酸分析}

中性塩可溶性画分扰よび中性塩不溶性画分を $6 \mathrm{~N}$ 共 沸塩酸に懸濁, 窒素着換後减圧封管 L, $110 \mathrm{C}, 24$ 時間 加木分解を行った，加木分解後，ロータリーエパポレー

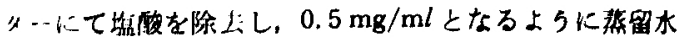

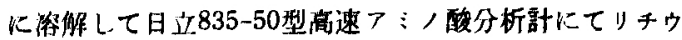

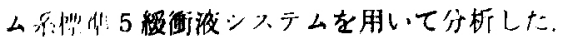

\section{4. 用元むよひ加水分解処理}

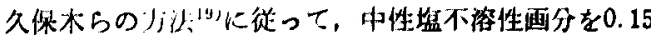

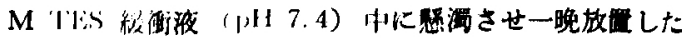
後，造元を行った，ななわち，0.5\% ['H]- $\mathrm{NaBH}_{4}$ (Ancrsham, $167 \mathrm{mCi} / \mathrm{mmol}$ ) $\mathrm{N}, \quad N$-Dirnethyl-forma-

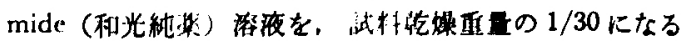

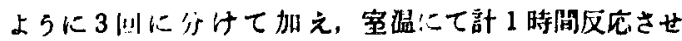
た， 2 N酢酸にて pH 4 まで下げて応を你止させ，

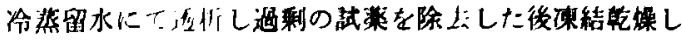
た.

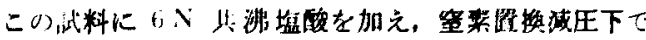
诗管し，1104(，24時间加水分解を行った媵，ロータリ ーエハホホレーターにて程酸を除吉し， $20 \mathrm{mg} / \mathrm{ml}$ となる よらに陚料を蒸留水に溶解した。

\section{5. 通元性架楺結合分析}

この遭元試料を $5 \mathrm{mg} / \mathrm{ml}$ となる上5に葬留水で希积 し還元性架橋秥合分析用試料とし，久保木5 析システムにより遭元性架楿結合分析を行った。すなわ ち、日立製汎用液体クロートグラフ 034 型装置（日立婥 脂 $\$ 2611 ， 0.9 \times 44 \mathrm{~cm} シ ゙+ケ ッ ト$ 付カラム, 60 C jを 用いて，0.2 M Na-クエン酸纊街液（pH 3.5）にて1

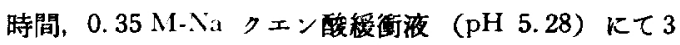
時間, 流速 $60 \mathrm{ml} / \mathrm{hr}$ て展開して架橋結合の分部を行っ た. 溶出液は分岐ボンプを用いて 2 分し，1/3をニンヒ トリン発色系に，2/3を放射能即定装圆に送った，放射 能測定は溶出液に 2 倍量の PCS 液体シンチレーション カクテル (Amersham) t混合し，建続放射能測定装置 (フロカ製ラジオクラフ)を用いて行った。

6. 非要元性架﨓結合（ピリジノリン）およびコラー ゲン関逗タンパク留架撟結合（ヒスチジノアラニ ン) の分析

$20 \mathrm{mg} / \mathrm{ml}$ の港度の遠元水解物を日立 L-8500 型高速 アミ，酸分析計に上りリチウム緩衙湤系で行った。 ピ リジリン，ヒスチジノフラニンの同定は，東京農工大 学藤本大三郎教授より恵与された標準サンブルを用いて 行った. アミ八酸分析系上の容出位置が他のピークと 重ならないことをいくつかの異なった楥衡夜系で確認 し ${ }^{20)}$ ，今回はピリジノリンの分析には pH3.6, $60^{\circ} \mathrm{C}$, ヒスチジノアラニンでは $\mathrm{pH} 4.1,60^{\circ} \mathrm{C}$ の系を用いた.

\section{7. ペプシン可溶性コラーゲンによる型分析}

1）ペプシン可容性コラーダンの調製

ヒトおよびブタ関節円板の中性塩不溶性画分を $0.5 \mathrm{M}$ 酢酸中で試料の $1 / 10$ 量のペプシン(Sigma, 2,900 units/ $\mathrm{mg}$ ）を用い， $4^{\circ} \mathrm{C}$ にて 24 時間消化を行い $100,000 \times \mathrm{g}$ ， 60分遠心し，残椬については同様の操作を繰り返した。 5 回の消化によって得られた上清に終浱度 $1.5 \mathrm{M}$ とな 


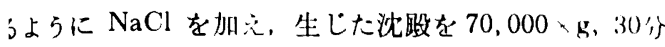
彭して集め，冷蒸留水に対し透析脱蒩を行的た後，凍 吉乾燥しペプシン可溶性コラーダンとした。

2）途中還元ゲル電気泳動

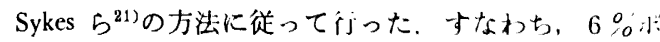

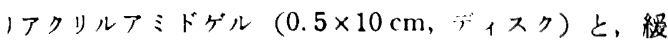

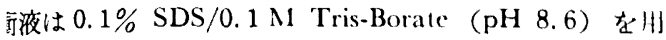
、陚料は $2 \% \mathrm{SDS} / 30 \%$ ワリセロール/2M成慗/0.02

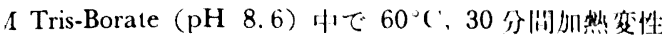
巳せ，泳動開始娞䄪 $1.2 \mathrm{~mm}$ 移政したところで川川:し，

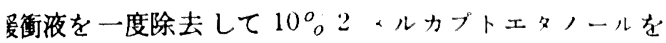
テル上部に 1 時間作用させて迩元を行った。

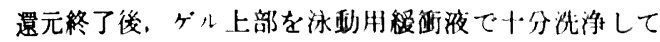
手ひ電気泳動を継䌇し，全部で䄪 $9 \mathrm{~cm}$ 泳動した，泳動 冬了後, ゲルを $0.25_{0}^{\circ}$ クマシーブリリアントブルー $\mathrm{R}$ 50 染色を行い，7.5 0 。酢酸，5\%×夕人一儿水溶液で 跑した。

\section{8. ブロムシアン $(\mathbf{C N B r})$ 分解法による型分析}

1) ブロムシアン分解法

ヒト関節円板のペプンンによる可溶化が汪とんど困難 こあったためブロムシアン分解を行い，ヒトおよびブタ 目節円板の $1 \mathrm{M} \mathrm{NaCl}$ 不㴼性两分についてブロムシア パプチトかから型分析を陚みた22）陚料の約100 倍量 $370 \%$ キ酸に窒素ガスを十分吹き込んだ後, 試料の約 2 刍重量のブロムシアンを加えて密栓し， 25 ( て て 6 時間 沁させた，その後，遠心 $(5,000 \times \mathrm{g}, 20$ 分）し，上清 冷蒸留水にて10倍希积し，ただちに凍結漧燥した。

またブタ皮庯より抽出した I 型および I 型＋林型コ ;ーダンを同様の方法でブロムシアン分解し，I 型およ 「III型コラーゲン由来プロムシフンペプチドの確認に用 な。

2) SDS ポリアクリルアミドゲル電気泳動

Laemmli ${ }^{23)}$ の方法に準じて SDS ポリアクリルアミト 沟泳動を行った，2.5\%の濃縮ゲル， $12.5 \%$ の分離の :リフクリルアミドスラブゲルを用い，緩衝液は $0.1 \%$ DS/0.025 M Tris-HCl/0.192 M クリンン ( $\mathrm{pH} \mathrm{8.3)}$ :用いた。試料は $2 \% \mathrm{SDS} / 25 \%$ クリセロール/5\%2ルカプトェタノール $/ 2 \mathrm{M}$ 尿素 $/ 0.0625 \mathrm{M}$ Tris- $\mathrm{HCl}$ JH 6.8) 中で $60^{\circ} \mathrm{C}, 30$ 分間加熱变性させた。泳動終 “後, ゲルを0. $25 \%$ クマンーブリリアントブルーR-250 色を行い，30\% メタノール/10\%酰酸にて脱色した。

\section{結果}

\section{1. 水分含量}

ブタ関節円板の水分含量は，生後 6 か月では 60.7 $\therefore .4 \%$ ，平均 $61.4 \%$ であり， 4 年では60.1〜66.6\%，平 61.3\%であった。 また，ヒトでは40藏〜85歳にわたる 検体についてその検索を行ったが，69.3〜75.4\%，
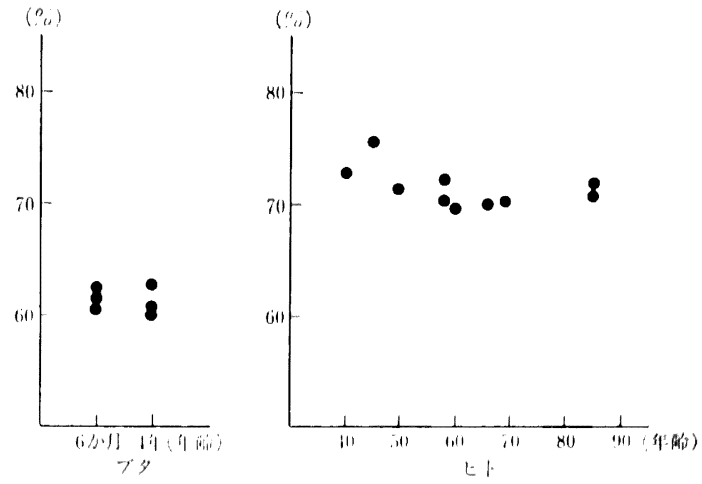

图3関節队板の水分含最

表 1 䦌節焖板（中性塩不溶性画分）のアミノ酸 組成

\begin{tabular}{|c|c|c|c|c|c|c|}
\hline & ブ & צ & & 七 & 卜 & \\
\hline & $(6$ 力月 $)$ & （ 4 年） & (26 放) & $(40$ 茼) & (50紫) & (75放) \\
\hline Hyp & 88 & 99 & 98 & 98 & 94 & 93 \\
\hline Asp & 49 & 41 & 38 & 37 & 43 & 41 \\
\hline Thr & 25 & 19 & 19 & 18 & 19 & 18 \\
\hline Ser & 41 & 36 & 33 & 35 & 37 & 34 \\
\hline Glu & 78 & 73 & 70 & 71 & 75 & 76 \\
\hline Pro & 117 & 130 & 126 & 126 & 119 & 121 \\
\hline Gly & 288 & 315 & 320 & 322 & 325 & 332 \\
\hline Ala & 99 & 106 & 100 & 102 & 104 & 109 \\
\hline Val & 30 & 26 & 28 & 25 & 25 & 26 \\
\hline Met & 7 & 5 & 7 & 7 & 8 & 9 \\
\hline Cys & 3 & 1 & 1 & 1 & 1.5 & 0.5 \\
\hline Ile & 15 & 11 & 13 & 12 & 14 & 13 \\
\hline Leu & 37 & 28 & 29 & 29 & 29 & 28 \\
\hline Tyr & 10 & 6 & 6 & 6 & 5 & 4 \\
\hline Phe & 19 & 16 & 15 & 14 & 14 & 14 \\
\hline $\mathrm{Hyl}$ & 8 & 9 & 8 & 9 & 8 & 8 \\
\hline Lys & 28 & 23 & 33 & 34 & 24 & 22 \\
\hline His & 9 & 6 & 7 & 7 & 7 & 5 \\
\hline Arg & 49 & 50 & 49 & 48 & 48 & 47 \\
\hline
\end{tabular}

[残基数 $/ 1,000$ 残基

平均 $71.7 \%$ であった。こ札らは特に年龄的な変化は認め られなかった（図了）.

\section{2. アミノ酸分析およびコラーゲン含量}

各試料の中性塩不溶性画分のアミ，酸分析の結果の一 部を表 1 に示した。 グリシンが全アミノ酸残基数の約 1/3を占め，をた，ヒドロキシプロリンも全残基数の約 1/10を占め, 各試料か大部分コラーゲンより構成されて いることが確認された。 
表 2 ஃラーゲンの川浴性

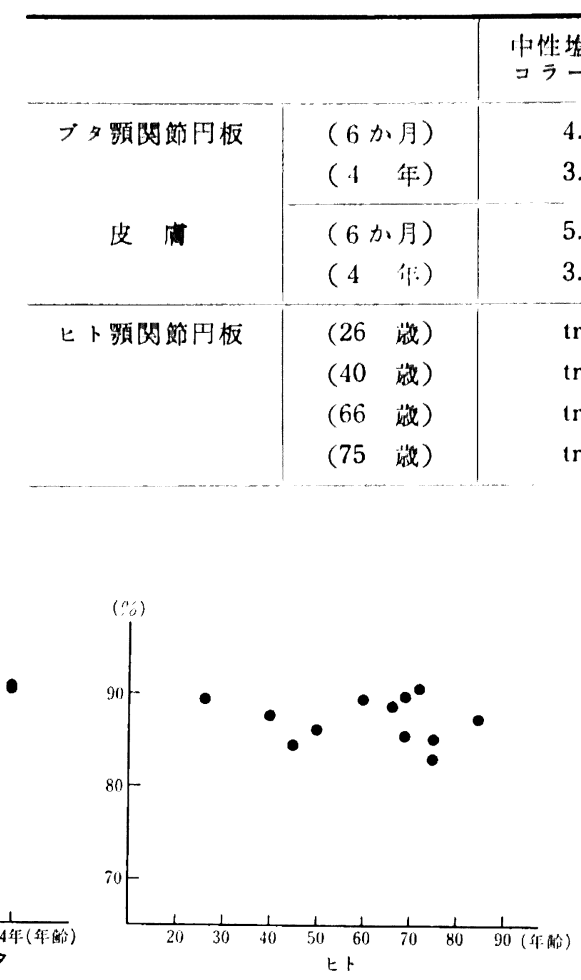

図 4 関節円板の全タンパク質に占めるコラーゲン の比率

これらのヒドロキシプロリン含有量からコラーゲン含 量を算出し, 関節円板の全タンバクに占めるコラーゲン の比率を調べた（図 4 ）。ブタでは生後 6 か月と 4 年と でそれぞれ組織乾燥重量当たり平均 $81.9 \%$ ，90.3\%であ り, 加龄によりコラーゲン量の增加が認められた。 ヒト では26〜85歳，12検体を調べたが82.9～90.0\%であり， 加龄変化による有意の増減傾向を示さなかった。これら は平均すると $87.1 \%$ であった。

\section{3. コラーゲンの可溶性}

生後 6 か月のブタ関節円板の中性塩可溶性コラーゲン は全ュラーゲンの $4.26 \% ， 4$ 年のそれは $3.61 \%$ であっ た. ペプシン処理によって可溶性は增加し，前者は 64.6 \%，後者は $46.6 \%$ となった，対照として各年跲のブタ皮 層コラーゲンの可溶性を同時に測定したが，中性塩可溶 性コラーゲンは 6 か月では $5.28 \% ， 4$ 年で $3.14 \%$ ，ペプ シン可溶性コラーゲンはおのおの $96.2 \%, 89.9 \%$ を示 し, 加此命による抽出性の低下が各組織において認められ た。また，ヒト関節円板は中性塩およびペプシン溶液に 対しほとんど抽出されなかった（表 2). プロムシアン による分解率をみると，6か月のブタでは関節円板・皮 虑ともに $90 \%$ 以上が分解され，ヒトでは30.3 58.0\%と
加柃による変化が顕著にみられた（表 2 ）。

\section{4. 還元性架棌結合分析}

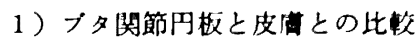

ブタ関節円板および皮成橪成コラーダンの這元性架 橋のラジオクロマトクラムバターンにおいては初めに $\left[{ }^{3} \mathrm{H}\right]-\mathrm{H}_{2} \mathrm{O}$ か;, 粘いて Dihydroxynorleucine: DHNL, Hydroxynorleucine: $\mathrm{H} N \mathrm{~L}$, Chloronorleucine: $\mathrm{C} \times L$ いった架橋前駆体および2つの倦元生物質，Hexitollysine: A1, Hexitollysine anhydride: A2 が出し，その 後に還元性架橋として重要な Dihydroxylysinonorleucine (DHLNL), Hydroxylysinonorleucine (HLNL), Histidinohydroxymerodesmosine (HHMD) かi溶出した（因 5 ).

関節円板，皮廂はそれぞれ組織および年踰差による異 なったクロマトハターンを示した。 また，分析に当たり 各試料についてラペルした放射能が同量となるように チャージしたが，関節円板，皮唐ともに加哈によって DHLNL と HLNL のピークが影著に減少した。主要 な3 種の架橋結合の相対量を明確にするためピーク面積 の割合を表 $3 に$ 示したが、これよりこれら2つの組織に おいて，加㱓により DHLNL および HLNL は減少す るか：HHMD の相対量の増加が認められた。

コラーゲン代謝の一つの指摽とされている DHLNL/ HLNL の比は関節円板では 6 か月で $1.00,4$ 年で 0.97, 皮慮においてはそれぞれ0.23，0.17であり，各組織にお いて加龄により減少したが，その割合は皮唐のほうがわ ずかに大であるように思われた，次に，還元性架橋分析 に用いた試料をアミノ酸分析して，そのヒドロキシプロ リン量を求めヒドロキシプロリン当たりの各還元性架橋 結合量を算出し，コラーゲン当たりの量の指標とした （図 6). 皮覻に比へ，関節円板ではコラーゲン当たり HLNL，HHMD 量が少ないことが示唆され，また，と ちらの組織においても加龄による架橋量の減少が羿めら れた。すなわち 3 種の還元性架橋の相対的な割合では加 


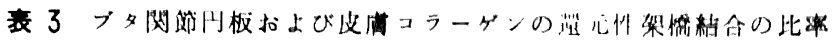

\begin{tabular}{|c|c|c|c|c|c|}
\hline & & DILNI. & III.NL & HHMD & JHI.NI,/HIANI, \\
\hline \multirow[t]{2}{*}{ ブタ罰関䬣円板 } & ((口か月) & $29.7 \%$ & $29.8 \%$ & $40.5 \%$ & 1.00 \\
\hline & ( 4 年) & 25.1 & 25.9 & 49.0 & 0.97 \\
\hline \multirow[t]{2}{*}{ ブタ皮庙 } & (6力月） & 8.5 & 37.4 & 51.2 & $0.2: 3$ \\
\hline & （ 4 年） & 5.7 & 32.9 & 61.3 & 0.17 \\
\hline
\end{tabular}

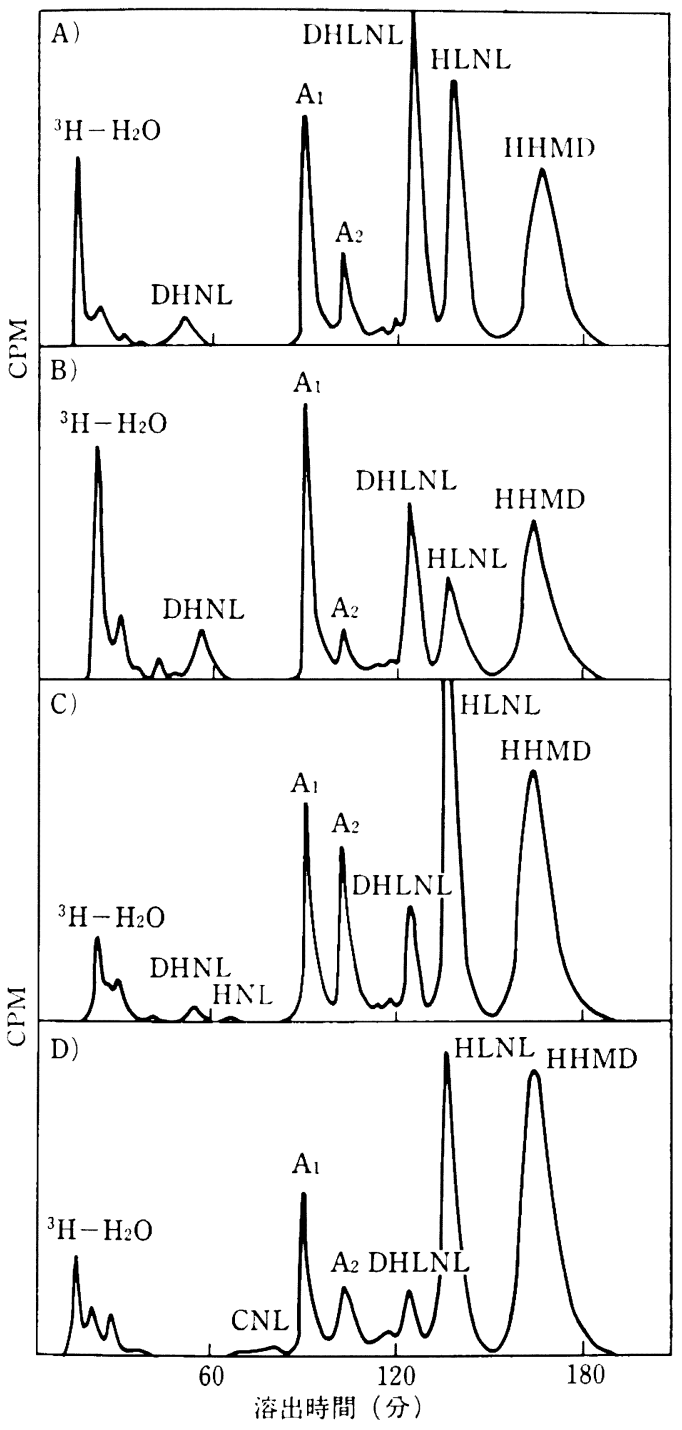

図 5 ブタ関節円板および皮膚のコラーゲン還元性 架橋結合溶出パーン
A）関節円板（6か月）
B ) 関節円板 $(4$
年） C）皮盧（6か月）
D) 皮席 $(4$ 年)

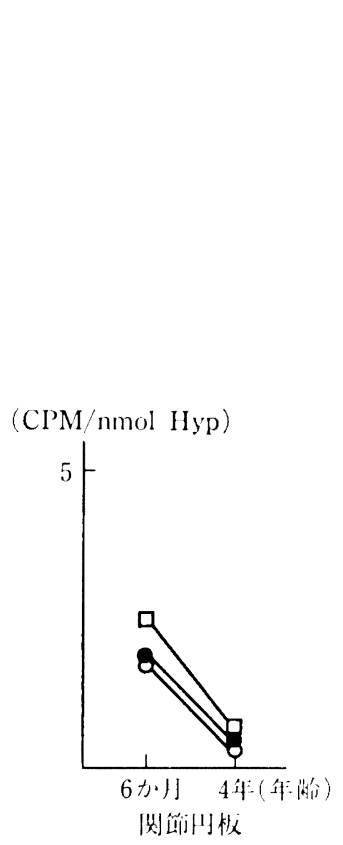

(CPM/nmol Ily,

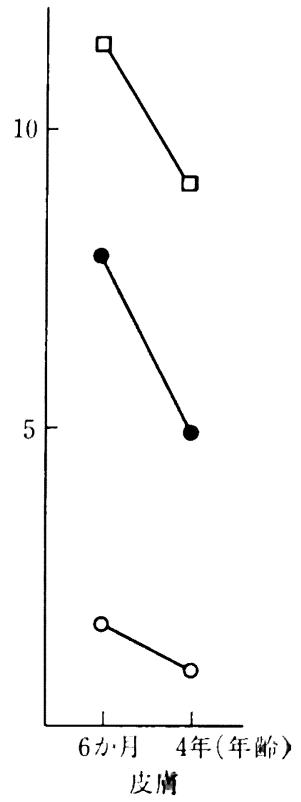

図 6 ブタ関節円板，皮间に扣けるコラーゲン当 たりの各還元性架橋結合量, 綎軸を CPM/ nmol Hyp とした

$\bigcirc$ DHLNL HLNL $\square$ HHMD

㱓によって DHLNL, HLNL の減少, HHMD の増加 がみられたが,コラーゲン当たりの架橋量についてみる といずれも減少していることが観察された。ささらに皮庙 においては生後 4 年時において H HLNL, HHMD か 多く存在していた。

2) ヒト関節円板について

ヒト関節円板コラーゲンの還元性架橋のクロマトグ ムパターンでは, ブタの場合と比較して還元性架橋であ る DHLNL, HLNL, HHMD のピークが低く, 還元性 物質であるA1 のピークが顕著に高いことが観察された （図 7）。D）はC）の関節円板にみられた穿孔部周囲を 採取して分析に供したもので，前駆体のピーク以外で は,さらにその周囲組織であるC）との架橋パターンで 大きな差異は認められなかった。これら4例を合わせ還 


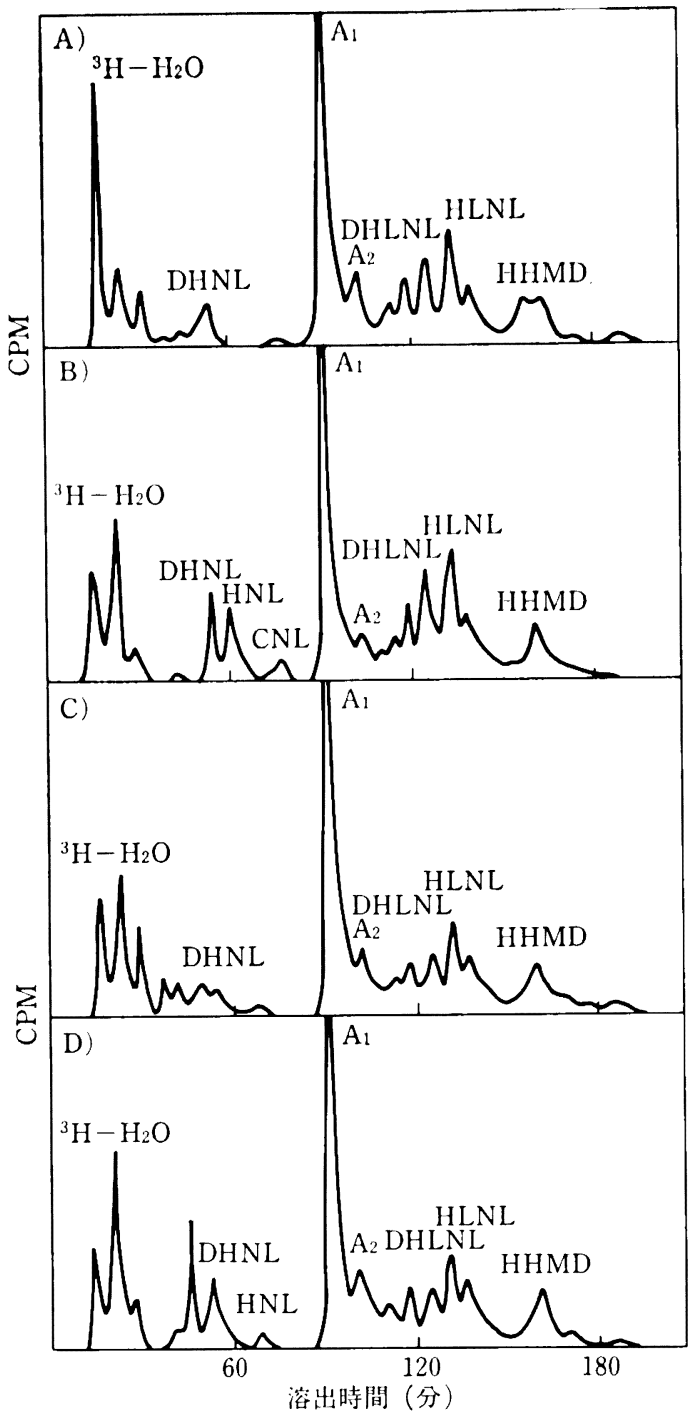

图 7 ヒト関節円板のコラーゲン還元性架橋結合溶 出ハターン
A) 26 藏 B ) 50 藏
C) 75 筬 穿孔部周囲

元修:梁灀分析を行ったい10例について，フタの場合之同

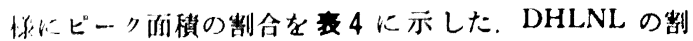
合は $18.2 \sim 33.1 \%$ ，HLNL は 37.9〜 54.3\%， HHMD は20.6〜44.2\%であった． DHLNL/HLNL の比は0.35 〜0.82であり，加粭によって若下の诚少傾向を小した。

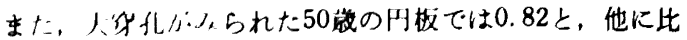
恔して大きな优を小した。

\section{5. 非通元性架满結合分析}

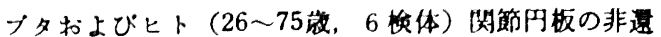

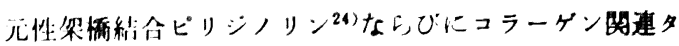
ンパク筫の架橋秥合であるヒスチジフラニン゙につい て，アミ，酸分析咶上り得たそれらの测定值を，同侎に して得たヒドロキンフロリン $300 \mathrm{nmol}$ 当たりに算出し. コラーゲン当たりの指榇としてはした（表5）。 ブタで はピリシリノリンは化後 6 か.月時で $0.67 \mathrm{nmol}, 4$ 年時 で $0.47 \mathrm{nmol}$ と加㟙により娍少を示したが，ヒスチシ ノアラニンは枱出限界以下であった。 ヒトてはピリジ

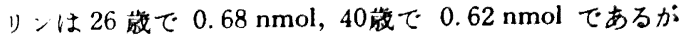
69 紫で $0.28 \mathrm{nmol}, 75$ 歳では $0.14 \mathrm{nmol}$ と加能によっ て減少を示した。また，75歳の症例でっんた関節円板

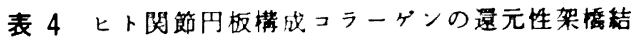
合の比事

\begin{tabular}{|c|c|c|c|c|c|c|}
\hline 店例 & 年跑 & 性 & DHLNL & HLNL & HHMD & $\begin{array}{c}\text { DHLNL/ } \\
\text { HLNL }\end{array}$ \\
\hline 1 & 26 & 우 & $20.4 \%$ & $43.5 \%$ & $36.1 \%$ & 0.47 \\
\hline 2 & 40 & $\delta$ & 20.5 & 42.5 & 37.0 & 0.48 \\
\hline 3 & 50 & $\delta$ & 31.4 & 48.0 & 20.6 & 0.65 \\
\hline $4 *$ & 50 & $\hat{\sigma}$ & 33.1 & 40.5 & 26.4 & 0.82 \\
\hline 5 & 60 & $\delta$ & 18.2 & 42.9 & 39.8 & 0.42 \\
\hline 6 & 69 & 우 & 21.0 & 54.3 & 24.7 & 0.39 \\
\hline 7 & 69 & $\delta$ & 18.3 & 51.9 & 29.8 & 0.35 \\
\hline 8 & 73 & 우 & 18.9 & 37.9 & 44.2 & 0.48 \\
\hline 9 & 75 & 우 & 18.8 & 53.3 & 27.9 & 0.35 \\
\hline $10^{*}$ & 75 & 우 & 18.2 & 52.7 & 29.2 & 0.35 \\
\hline
\end{tabular}

*は呀孔部周囲の円板組暂を表す 症例 4 は大骂孔を伴 5 ○の 症例 10 は小呀孔周囲の円板租简で, 症例 9 : にその周囲部の队板組である

表 5 ピリジノリン (Pyr) 扰よびヒスチジフラニン (HAL) の分析

\begin{tabular}{|c|c|c|c|c|c|c|c|c|}
\hline & \multicolumn{2}{|l|}{7} & \multicolumn{3}{|r|}{ ヒ } & \multicolumn{2}{|l|}{ r } & \\
\hline & ( 6 力月) & ( 4 年) & 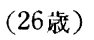 & （40藏） & （69歳） & （73歳） & （75藏） & $\mathrm{P}$ \\
\hline Pyr & 0.67 & 0.47 & 0.68 & 0.62 & 0.28 & 0.20 & 0.14 & 0.22 \\
\hline $\mathrm{HAL}$ & * & * & * & * & 0.25 & 0.24 & 0.29 & 0.59 \\
\hline
\end{tabular}

*: $0.05>$ で検出限界以下

[nmol/Hyp $300 \mathrm{nmol}]$

$\mathrm{P}$ : 第孔部周囲 


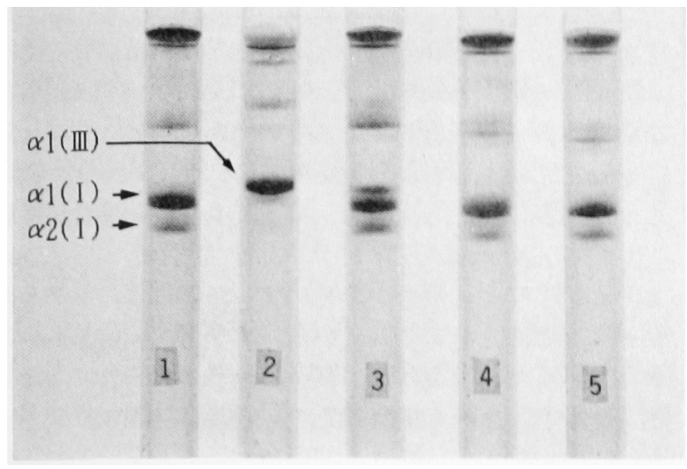

图 8 ベブンン可溶性コラーゲンの途中飠元ゲル霆 気泳動像 (6\%ポリフクリルフミドゲル) 1：I 型コラーダン，2：III型コラーダン， $3:$ : タ皮间（生媵 6 か月） 4 : ブタ関節円 板 (生啳 6 か月), 5 : ブタ阙節円板（生媵 4 年)

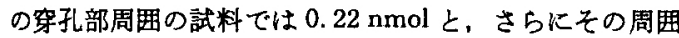
の正常と考充られる組織に比し，やや高い值であった， ヒスチジノアラニンは40藏までは検出限界以下であり， 69歳ては $0.25 \mathrm{nmol}, 73$ 歳で $0.24 \mathrm{nmol}, 75$ 歳で 0.29 $\mathrm{nmol}$ であった，穿孔部周囲の試料では $0.59 \mathrm{nmol}$ と約 2 倍の高い値を示した。

\section{6. コラーゲン型分析}

1）途中還元ゲル電気泳動

ペブシン可溶性コラーゲンの SDS ディスク電気泳動 ペターンを图 8 に示した。I型スタンダードと同様，関 節円板では $\alpha 1$ （I）， $\alpha 2$ （I）のパンドが認められ， これらのデンシトメーターによる比率は 2 .1を示し た。これより生後 6 か月および 4 年のプタ関節円板が I 型コラーゲンから構成されていることが示唆された。

2) ブロムシアンベプチドの SDS スラブ電気泳動

ヒト関節円板がペプシン楁液によりほ上んど抽出され ないこと、拉よびブタ関節円板に打いても生後 6 か月で その抽出率が $64.6 \%$ といらことより，ブロムシフン分解 を行い，そのブロムシアンベブチドの電気泳動パターン から型分析を試みた。

ブタ関節円板には痕跡程 度に II 型コラーゲン由来の $\alpha 1$ (II)-CB-5，9 が認められた。 ヒトの泳動像はI 型 コラーゲンのパターンを示し， $\alpha 1$ (II)-CB-5, 9 のパ ンドはみられなかった（図9）。

\section{考察}

買関節は側頭骨下顎窩扰よび関節結節と下買骨関節突 起とによって構成される二軸性の蝶番滑走関節である. 両者の間には関節円板が介在し上下関節䦡に二分され， こ机によって下㴿頭の前方滑走運動が可能となる ${ }^{25)}$ ，七

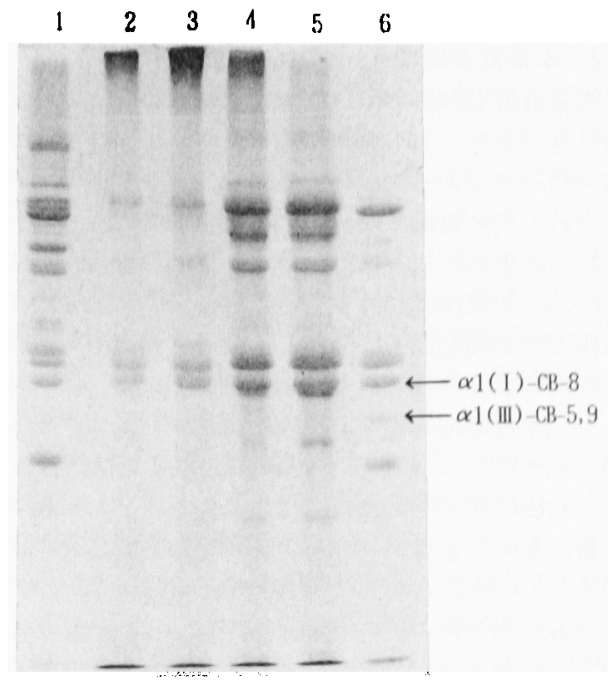

图 $9 \mathrm{CNBr}$ 分解法による12.5\%ポリフクリルフ ドゲル筐気泳䡃像

1：I型コラータン，2：上卜関節円板 (40

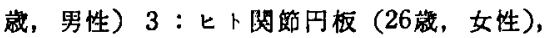
4: プタ网節円板（生後 4 年） 5 : プタ関節 円板 (生後 6 か月)，6：I+吕型コラーゲ ข

トの関節円板は，古くから組織学的な研究材料として扱 われてきて㧍り，そのコラーゲン線維走行 ${ }^{3,28,27) な と ゙ に ~}$ ついて種々言及されてきた。 また，ヒト胎况を用いた関 節円板の prenatal growth についての研究むいくつか みられる 28,29)，このように関節円板の組織学的な研究は 多くなされているものの，関節円板を罎成する主体であ るコラーゲン線維の化学的性状，また，病的変化に関す る詳細な報告はなされていないのが現状である。このた め本研究では, コラーダンに機栈的強度と化学的安定性 をるたらす架橋結合を中心とした関節円板の生化学的分 析を試みた。

\section{1. 研究材料について}

ヒト関節円板は 26 ～ 85 歳にわたる 16 症例を採取し得 た，架橋構造や分子レベルからコラーダンの変化をみて いく場合，より幼若で未成熟な組峨を分析し，そこから 加龄変化を追及していくことが重要であろらと考える が，本研究に際しては幼若検体からの試料を得ることが できなかったそそこで，ヒトに類似した咬合様式を有す るプタを用い，物理的年龄の低い動物に扣ける関節円板 コラーダンの特徽をとら京よらと試みた。

Ström ${ }^{30)}$ は生後 1 年のブタの顎関節之咀禹筋を調へ 両者の解剖学的類似性を指摘し, 咀嚼系の機能研究にと ってブタは有用であると述へている，ブタの生後 6 か月 および 4 年がヒトのどれ位の年龄に相当するのかは明確 にすることはできなかったが，すでに6か月時に扰いて 
生殖可能である。

\section{2. 水分およびコラーゲン含田について}

水分含最をみると，ブタではり後 6 か川，4 代ともに

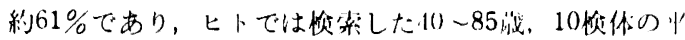

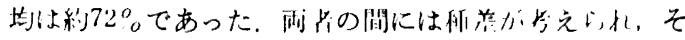

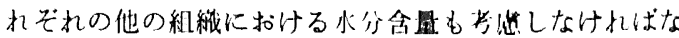
らないと思われる。岡野 ${ }^{31}$ は上卜椎泊板線䊶輸の水分众 1月は20３0㫌代まで減少し，以德汪とんど一定であり，

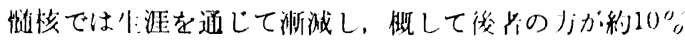
前後高い水分含量を小したと報告している。訬桨ひコラ

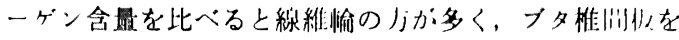

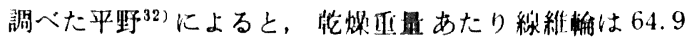

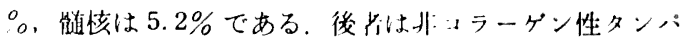
ク貿が多いことでブロテオグリカンなどが水分の保持に 関係していることが考之られ，水分含量の多い、因と思 われる。ブタおよびヒト関節円板は乾燥重量あたり約 80〜 90\%のコラーゲン含量を示したか，水分含量におい てはコラーゲン含量がり近い線維輪に似た增減傾向を 示寸ものと考えられる.

フミノ酸分析の結果, プタおよびヒト関節円板が大部 分コラーゲンから構成されていることが確認され，これ らのヒドロキンプロリン量からコラーゲン含量を算出し たが，ブタでは年齢に上る增加が認められ，生後 6 か月 では約 $82 \% ， 4$ 年では約90\%であった.

ヒトの骨扣よび関節軟骨のコラーゲン含量の変化は,

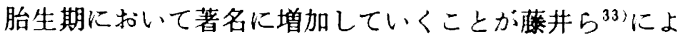
り示されている。すなわち，前者は胎生 4 か月で組織湿 性重量の䄪 $4 \%$ ，後者は $2.4 \%$ となっているか，胎生 10 か月になると，骨では湿性重量の約 $9 \%$ ，軟骨のそれは 約 $7 \%$ にさて達する。.さらに生後 3 歳になると骨のコラ ーゲン含量は湿性重量の約 $25 \%$, 軟骨は約 $20 \%$ となり, その後89歳に至るまでこれらの值はほとんど変化が認め られない，本研究におけると卜関節円板の場合，年龄に よる增隇傾向は検索を行った26歳以上ではみられなかっ たが、ブタにおけるデータも考磨すると骨や関節軟骨と 同様に，関節円板においてもある年龄または一定量に達 してしまらとコラーダン量は変化しないものと思われ る.

ブタ関節円板において生後 6 か月のものに比べ 4 年の ものではコラーゲン含量が増加していたが，これは 6 か 月のブタ関節円板が末だ機能的に成熟していないことに よるものと考えられる.

ヒト関節円板について, 生化学的にコラーゲン量を求 めたデータはみられないか，Thilander ${ }^{27)} は ， 14$ 週の胎 児から65歳にわたる各年代のヒト関節円板58検体につい て組織学的に観察し，加龄によりコラーゲン線維が増加 することを報告している。 また, Boucher ${ }^{34)}$, Poswillo ${ }^{35)}$, Barbenel ${ }^{36)}$ らは顎関節の荷重負担について解剖学的, 生 理学的に検索し，買関節が負荷関節であると報告してい
らか、これらがコラーグン量の增加と関逃していること も来兄られる、これらのことから，関節円板は比䑤的早

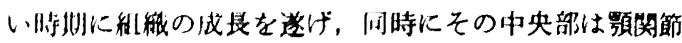

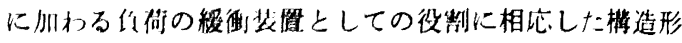
热を倘えていくものと教えられる。

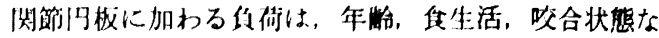
どによって人るな゙リエーンョンを生ずると考えられ

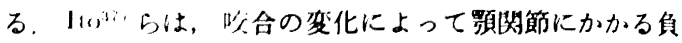
衍が買なることを赫告している，本研究ではと卜桥体に おいてて，尘前の咬合状態に咸与る情報は得られず，した

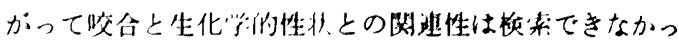
t.

\section{3. 架桸結合について}

\section{1）䢱元珄架橋結台}

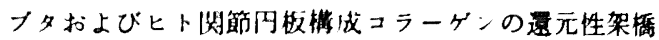
結合のパターンはそれぞれ一定の特徽を持っており，特 に，前者においてては生後 6 か月方 4 年の陚料において明

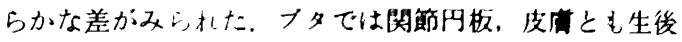
6 か月と 4 年のものを比べると选元性架檑量の減少か認

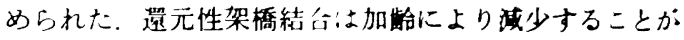
種々の組織に扰いて確かめられている ${ }^{9,38,39)}$ が、これら の組織も同様の傾向を示した。ヒト関節円板において は，ブタと比へて，年踰に関保なく遥元性架橋量はさら に少なかった。 ヒト関節円板は噮元性架霞結合に関し て，少なくとも娭索した 26 歳から 75 歳の試料において は，加路に上る变化を受、たくい組織であることが示唆 された

ヒトでは還元性物質 A1 (Hexitollysine) が，今回検 索したどの年踰時においても䫒著に高いピークを示し た.A1 は Robins ら ${ }^{40}$ によってへキッースとリシンが シッフ塩基で結合したものであると報告され，また，軟 組織の加龄に伴って增加するともいわれている ${ }^{16,40)}$ 骨, 軟骨, 皮唐, 歯肉なと，他の組嬂汇おける逼元性架 橋結合の溶出パターンと比べ，ヒト関節円板のそれは， A1 のピークが著しく高いことが特致と思われる.他の 組織に比べヒト関節円板は不溶性が高く, 中性塩および ペプシン溶液に対しはとんど抽出きれなかったか，この 不溶性と A1 量の増加とが関連しているかもしれない

Takagi ら ${ }^{41)}$ はヒト象牙質コラーゲンの還元性架橋結合 を調へ，象牙質形成不全症において正常よりも DHLNL が少なく A 1，A 2 が多いことを報告している。また， この場合正常に比べ不溶性が高く, ペプシンに対してほ とんど溶解せず，ブロムシフン分解でも分解率が低いと 述べている42) 現時点においてA1の詳紐は明らかでな く，今後の検討が必要であろう。

久保木ら ${ }^{16,18,19)}$ により, DHLNL/HLNL の比は幼若 で活発にコラーゲンの合成と線維形成を行っている組織 ほど高い值となり，また，骨や象牙質などの硬組織では DHLNL の方が多く，この值は 1 以上となり，歯肉, 


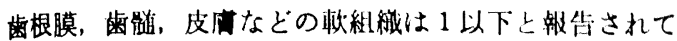
いる，さらに彼は，皮呞なとの杴組峨に括いても，胎少 期または非常に奻若でコラーダン合成の証盛な堽划には DHLHL/HLNL の比が高い事实から，石灰化組織では

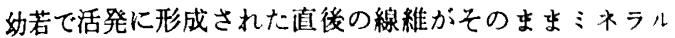
の中に閉じ込められて涷結された結果であると考察して

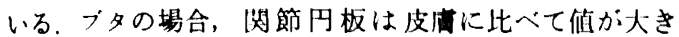

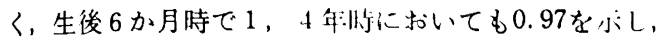
硬組織に近い值を示した。しかし，ヒトの関䬦板悄，骨 についての藤井ら ${ }^{43)}$ の報告によると，DHLNL/HLNL

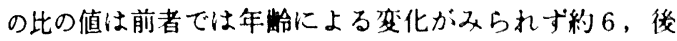

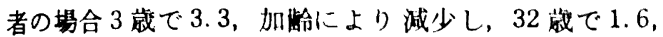

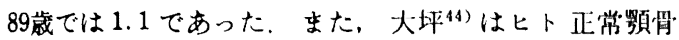

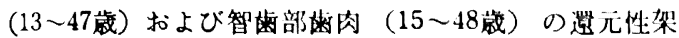
橋結合を検索し，その DHLHL/HLNL の比は，前者 では0.4〜1.2, 後者では1.1〜1.7であり，加龄による增 減関保は特にみられなかったと述へてている。

今回娭索したヒト関節円板では DHLNL/HLNL の 比は 0.35 0.82であり，いずれも軟組織に特有の値を 示した，大穿孔のある 50 歳の症例の関節円板では， DHLNL/HLNL の比は0.82 と他よりも高い值であった か，これは穿孔部周囲にわずかに残存した円板組織を分 析したためと考えられる。 またこれらの值よりヒト関 節円板の代謝活性は低いと考えられるか，このことは少 なくとも成人以降，正常な関節円板では線維組織の改变 が起こりにくいといらことを示していると考えられ，実 祭，血管を含まず，関節㾋のみから栄羡供給を受けてい る関節円板中央部の解剖学的環境からも示唆されると思 われる.

2）非還元性架橋結合について

本研究ではつミノ酸分析計を用いて，非還元性架橋結 合ピリジノンおよびュラーゲン関連タンハク質架橋結 合ヒスチジノアラニンの直接定量を行った。

ピリジノリンは1977年, Fujimoto ら ${ }^{24)}$ によってウシ のフキレス腱のコラーゲンから螢光性を有する架橋アミ ノ酸として単離された成熟架橋である。ラットおよびヒ トの胁軟骨,アキレス腱のピリジノリン含量を調べた Moriguchi ら $\left.{ }^{45}\right)$ によると,ラットでは出生直後のコラー ケ゚ンにピリジノリンはほとんど含まれないか，成長とと もに増加がみられ，一方，ヒトでは出生から20歳頃まで 急増し，30歳頃より減少がみられたとのことである。

ピリジノリンは，本来 P-cellulose カラムを通し，さ らに䖝光測定を行って同定することが望ましいが，試料 の量的問題もあり, 本研究では標準物質との溶出位置の 一致を十分に確認して行った。

本研究で用いたプタにおけるピリジリンン量は，ヒド ロキシプロリン $300 \mathrm{nmol}$ 当たり，生後 6 か月で 0.67 $\mathrm{nmol}, 4$ 年で $0.47 \mathrm{nmol}$ とやや減少が少られた。 ヒト の值と比較したピリシノリン量の変化からも, 生後 6 か
月のブタはすでに成然㭗に達していることが示峻される

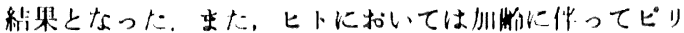

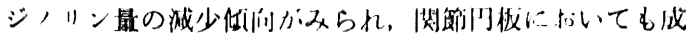

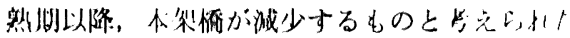

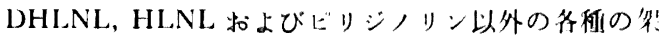

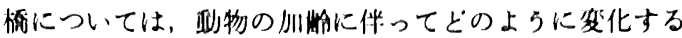
のか、維には汪とんどわかっていないのか現状である

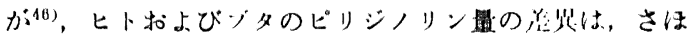

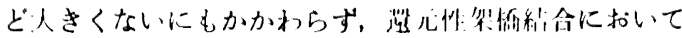
阿者は省しく出なる深出パターンを小した（衰了，5）。 このことは，七ト闺節门板では幼若な架恬から，ピリシ

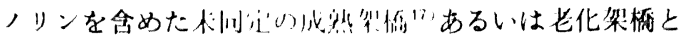
いわれるようなものへといちはやく枟換が谁友，それら が関節瓶板の機械的強度と不溶性に寄! 考えられる，夙節円板は関節液に浸って存在している が，その璒境下で二次的にさらに複稚な架橋形成が行わ れるであろらことが推察される。䫟関節液の成分，機能 的役割についてはいまだ詳細は不明であり，今後の課題 であろら。

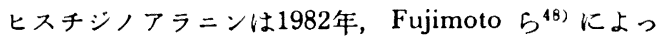
てヒト象牙質中に発見された架橋丁ミノ酸で，その後軟 骨や動脈壁なとでる発見されだ9) 当初はコラーダン間

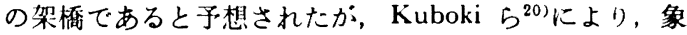
牙質に怙いてはリンタンパク質の成分であることが確認 され，以後コラーゲンと他のタンバク質との架橋である と考えられるようになっている。ヒスチジノラランン の存在に関しては, ある種の二枚貝に多く存在するこ $と^{50)}$, 顎口腔領域の軟組織, 硬組織疾患中に存在するこ と ${ }^{44)}$ が報告されているが，いまだ不明な点も多い，本研 究において，プタおよび26歳，40歳のヒトでは娭出限界 以下であったか，老化によって出現し，呀孔部周囲の円 板組織に多く存在することが涩められた。これらは関節 円板を構成するコラーゲンと，その中に存在するわずか な非コラーゲン性タンバクと結合していると考えられる か，今後，この架橋の性質が明らかにされるにつれ，本 データもより有意となるであろらと思われる。

\section{4. コラーゲン型分析について}

ブロムシフンペプチドの電気泳動による型分析によ り，ヒト関節円板は I 型から，ブタでは I 型と極く少量 の III 型から構成されていることが喼められた，ヒ卜瞵関 節半月板かＩ型から構成されていることは，平野 ${ }^{32)}$, 進

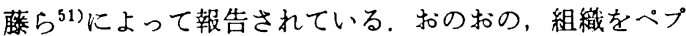
シン消化しており，前者の報告では 14 歳の滕半月板で $38.6 \%, 45$ 歳で $5.2 \%$, 後者では若年成人群で $20 \sim 30$ $\%$ ，高龄者群で 3〜 5\%と，低いながらも抽出されてい る。本研究に扒いて，ヒトの関節円板組織から型分析可 能なコラーダンはペプシンではほとんど抽出されなかっ た，この抽出率の差は顎関節円板と滕半月板の組織の違 いに由来するものかと思われる，すなわち，頡関節腔を 


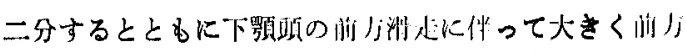

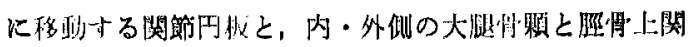
節面との閌の周边部汇介在し，それぞれ内侧半月化，外

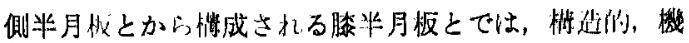
能的にかなりの差舆があり，このような機能上の相活に

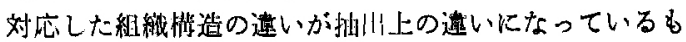

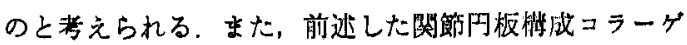

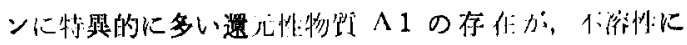
関連しているものと思われる。

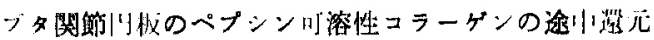

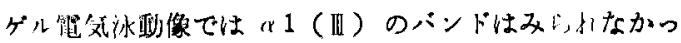
たが、ブロムシアン分解により，わをかであるが $\alpha 1$ (III)-(B-5，9 のパンドか倾䏣された。これは，抽出 （分解）率の違いに上るるのであると思われるまた。 アミノ酸分析の結果, 扔の怙のの試料にはシスチンが数 残基存在したが，これは开型コラーゲン由米であると思 われる。このことから，ヒト関節円板の場合もわずかな 卭型存在の可能性が教えられる.

Hirschmann $ら^{111}$ 恃，ウシ胎児の関節円板はＩ型およ び型から成っているが，四型は試料採取時に括ける周 用滑膜の混入であると考察している.今回, ブロムシア ンペプチドの電気泳動像からブタ関節円板でわずかな四 型の混入がみられたが，陚料採取部位から考えて関節円 板固有のむのであると思われる。主た，得られた電気泳 動像をデンシトメーターにて测定したが，明確なピーク を得られず，I型に対する芷型の割合を求めることはで きなかった。

\section{5. 関節円板の穿孔について}

関節円板の穿孔の原因としては，橉牙欠損に起因する 円板への応力の変化や損傷，栄着状態の変化などが考兄 られている52) 近年, 剖検などによって円板に穿孔がみ られる率は，Lietberg ら ${ }^{53)}$ にると $28 \%$ ，木野ら 19.2\%である. 本研究に際して採取したヒト関節円板は 合計16検体であり，このらら75歳の症例では円板関節面 外側部に，さらに50歳の症例において円板のほ注全体に 及ぶ穿孔が観察され，その割合は12.5\%であった。

75歳の症例において，穿孔部周囲組織をさらにその周 囲の円板組織と分けて採取し分析したが，穿孔部周囲と さらにその周团組織とでは，還元性架橋結合について明 確な差異は認められなかった。これは還元性架橋結合量 飞関連していると思われる。すなわちこのような年龄 では還元性架橋結合量が著しく減少しているために, 明 確な变化として現れなかったるのと考占られる。

これに代わって，コラーゲン関連タンパク質架橋結合 であるヒスチジノアラニンが老化に伴って出現し，ま た，穿孔部周囲で多く認められたことは，穿孔部に比較 的多くみられる類軟骨細胞（図 $10 \mathbf{a}, \mathbf{b}$ ) と関連して興 味深い. 組織学的には, 加龄によって関節円板のコラー ゲン線維間にこの類軟骨細胞が単独, あるいは数個ずつ

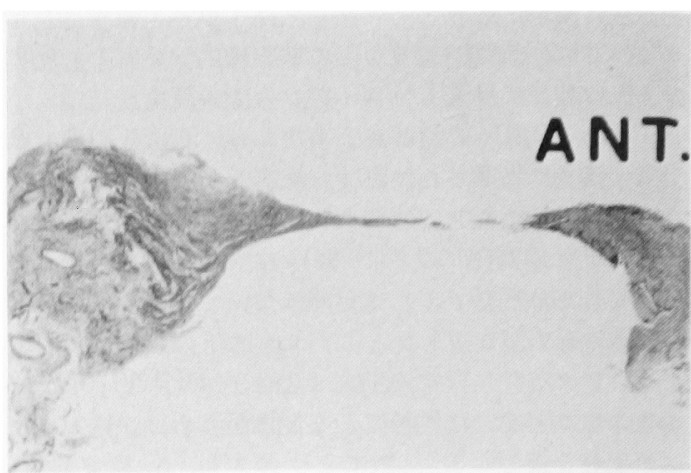

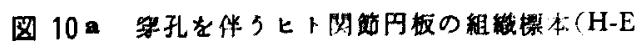
梁色, $\times 2$ )

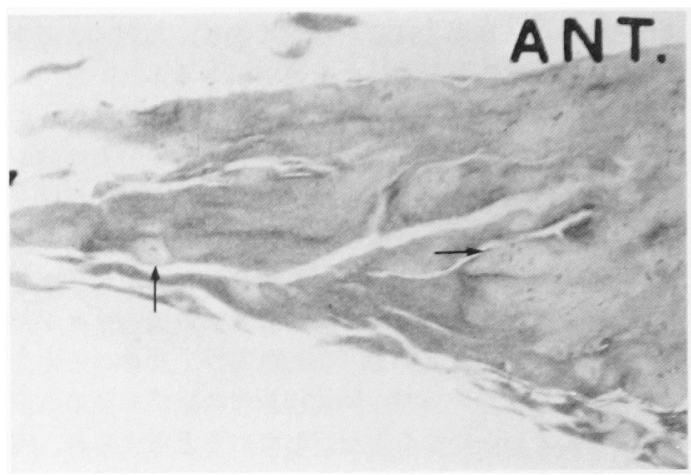

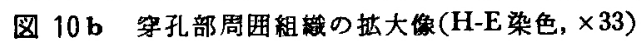
類政骨細胞がムられる（矢印）

列をなして存在するようになるとされこれは㖪や勒带 の付着部に打いて加踰とともに生じる变化と同様であ り，生理的なむのであると考えられている35)。これらの 変化が関節円板の穿孔とどのような関わりを持っている のかは現在のところ不明であるが，老化伴って增加す るとスチジノフラニンが, 円板穿孔部周囲において類軟 骨細胞の出現とともに増加したことは，このような病的 円板組織が加龄に伴ら変化と同様な変化を加速している ことを示唆しているものと考えられた。

\section{結}

ヒトおよびブタ関節円板を構成するコラーダンについ て生化学的な分析を行い, 次のような結果を得た。

1. ブタ関節円板の水分含量は生後 6 か月， 4 年飞打 いて，ともに約 $61 \%$ であった，40〜85歳にわたる10検体 について検索したとトでは平均すると約72\%であり、こ れらは特に年龄的な变化は認められなかった。

2. アミ，酸分析の結果，関節円板は大部分コラーグ ンより構成されていることが確認された。ブタおよびヒ 
ト関節円板の全タンパクに占かるコラーゲンの蚛介似，

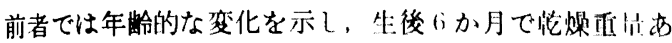
たり約 $82 \% ， 4$ 年で約 $90^{\circ}$ 。であった。 ヒトでは2はー85

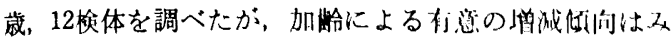
られず，平均約 $87 \%$ であった。

3. 関節円板を棈成するコラーゲンは大部分不浴性で あり，特にヒト関節円板は中性场およびペブシン深液に 対してはとんど抽出されなかった。プロムシフン分解に

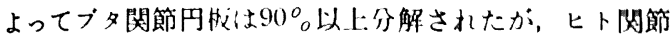

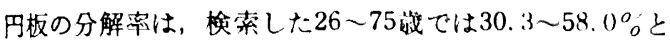
低かった。

4. 還元性架橋結合のハターンをみると，ブタ闵節队

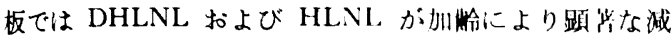
少を示した，ヒト网節円板ではこれら還元性架㛢のピー クは低く，還元性物質であるA1 がわわて多量に存 在し，26歳以上の年龄層では加龄による変化は特に熟め られなかった．DHLNL/HLNL の比は，ブタ関節円板 では生後 6 か月，4年ともに約 1 であり，ヒトでは0.35 〜0.65を示した。

5. ピリジノリンはプタ，ヒト関節円板に拈いてそれ ぞれ加齢により减少した。ヒスチジノアラニンはブタお よび40歳までのヒト関節円板では榆出限界以下であり， 老化に伴って検出された。

6. ブタ関節円板は I 型コラーケ゚ンとわずかな四型コ ラーゲンから，また，ヒト関節円板はI型コラーゲンよ り構成されていた。

7. 75 歳の症例でみられた穿孔部周囲の円板組織は他 に比ベヒスチジノアラニンが増加して扣り，組織学的に 穿孔部周囲に多くみられる類軟骨細胞との関連が示唆さ れた。

稿を終えるにあたりここ指導とこ烄閱を嚁りました塩 田重利教授，ならびに曾学部生化学教室, 佐々木哲教授

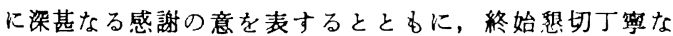
こ教授とこ校閲を睗りました北海道大学曾学部生化学教 室，久保木芳徳教授に表心より感謝を捧けます。

また，本研究に際し，多大なるご助言，ご鞭撻をいた たきました当教室木野孔司博士，ノースキャロライナ大 学, 津崎まり博士に深謝致します。

さらに, 種々のこ援助をいたたきました曾学部附属病 院㭘查部, 齿学部生化学数室, 北海道大学歯学部生化学 教窒ならびに当教室の諸先生方に厚く扰礼申し上げま t.

\section{引用 文 献}

1）上野 正：罰関節症の病因と治療。昭和菓訍 2: 121-130 1983.

2）高橋庄二郎，柴田考典：䫑関節症の基礎と臨

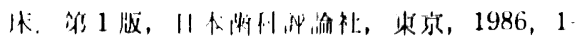
22 L'L.

3) Shapion, R.P.: Ilistoprathology associated with malposition of the human temporomatudibular joint (lise. ()ral Surg 55: 382-397 1983.

1) Isacsson, (i., Islueg, A., 41 al.: Intronal derangenent of the temporomandibular joint: Radiographic and histolengic changes anses iated with scvere pain. J Oral Maxillofac Surg 44: $771-7781986$.

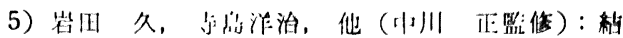

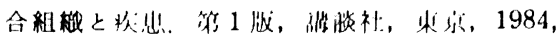
3-19, 82-86 i'l.

6) ( m.bold, W.R. and Pedrini, V.: P'psin-solubilized collagen of human nucleus pulposus and annulus fibrosus. Biochem Biophys Acta 434: 390-405 1976.

7) Eyre, D.R. and Muir, H.: Type I and II collagens in intervertebral disc: Interchanging radial distributions in annulus fibrosus. Biochem J 157: 267-270 1976.

8) Eyre, D.R. and Muir, H.: Quantitative analysis of type I and II collagens in human intervertebral discs at various ages. Biochem Biophys Acta 492: 29-42 1977.

9) Fujii, K., Kuboki, Y., et al.: Aging of human bone and articular cartilage collagen. Gerontology 22: 363-370 1976.

10) Granström, G. and Linde, A.: Glycosaminoglycans of tomporomandibular articular discs. Scand J Dent Res 81: 462-466 1973.

11) Hirschmann, P.N. and Shuttleworth, C.A.: The collagen composition of the mandibular joint of the calf. Archs Oral Biol 21: 771-773 1976.

12) Miller, E. J. and Matukas, V.J. . Chick cartilage collagen: A new type of $\alpha 1$ chain not present in bone or skin of the species. Proc Natl Acad Sci USA 64: 1264-1268 1969.

13) Miller, E. J.:Chemistry of the collagens and their distribution. Piez, K.A. and Reddi, A.H.: Extracellular Matrix Biochemistry. 1 st Ed, Elsevier Science Publishing C'o, New York, 1984, p 41-81.

14）久保林芳锶：口腔組織コラーゲンの生化学, 浜 田茂幸編：5蝕と料周病。第 2 巻, 第 1 版, 日 本绦科評論社, 東京, 1982, 199-243頁.

15）畑隆一郎：コラーゲン一その機能と代謝一 蛋白質，核酸，酵素 31：29-52 1986.

16）久保木芳镘, 津崎まり, 他：組織生化学検査法 (II)一結合組織をど5扱 5 か一、料科シャーナ ル 21: 355-363 1985.

17）三澤常美：サル顎関節関節円板に扮ける実験的 微細損稘の治瘾経過に関する組織学的観察。口 病誌 49：211-238 1982. 
18) Kuboki, I'., Takagi, T., et al.: Comparative collagen biochemistry of bovine periedoulium, gingiva, and dental pulp. J Dent Ris 60: 159-163 1981.

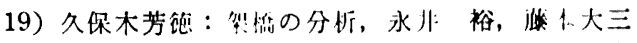

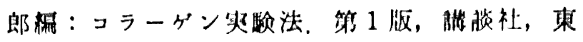
识，1985，119-234面.

20) Kuboki, Y., Fujisawa, R., ('t al.: Presence of lysinoalanine and histidinoalanine in bovine dentin phosphoprotein. Calcif Tissuc Int 36: 126-128 1984.

21) Sykes, B., Puddle, B., et al.: The estimation of two collagens from human dermis by interrupted gel electrophoresis. Biochem Biophys Res Commun 72: 1472-1480 1976.

22）久保木芳饨, 下川弥太, 他：コラーゲンの架 橋粘合の分析法一幽牙形成璣序への一つのフプ ローチ一读界展照 44: 97-104 1974.

23) Laemmli, U.K.. Cleavage of structural proteins during the assembly of the head of bacteriophage T 4 . Nature 227: 680-685 1970.

24) Fujimoto, D., Akiba, K., et al. . Isoration and characterization of a fluorescent material in bovine achilles tendon collagen. Biochem Biophys Res Commun 76: 1124-1129 1977.

25）木野孔司, 大西正俊：頡関節の解剖一関節腔内 壁表面の形態とその組織精造一。料科ジャーナ ル 16: 767-776 1982.

26) Rees, L.A.: The structuer and function of the mandibular joint. Br Dent J 96: 125-133 1954.

27) Thilander, B.: The structuer of the collagen of the temporomandibular disc in man. Acta Odont Scand 22: 135-149 1964.

28) Keith, D.: Development of the human temporomandibular joint. Br J Oral Surg 20: 217-224 1982.

29) Morimoto, K., Hashimoto, N., et al.: Prenatal developmental process of man temporomandibular joint. J Prosthet Dent 57: 723-730 1987.

30) Ström, D., Holm, S., et al.: Gross anatomy of the mandibular joint and masticatory muscles in the domestic pig (SUS SCROFA). Archs Oral Biol 11: 763-768 1986.

31）岡野 正：椎間板の物理化学的性状に関する実 匼的並びに臨床的研究. 特に親水性に就て。千 医会誌 36：270-301 1960.

32）平野秀夫：線稚性軟骨コラーゲンの特徵一特に 脊椎椎間板のコラーゲンタイプについて一，中 部整災誌 21：664-678 1978.

33）藤井克之, 暒原敏英, 他: 骨, 関節軟骨の老化 とコラーゲン. 整形外科 32: 416-424 1981.

34) Boucher, L.J.: Anatomy of the temporo- mandibular joint as it pertains to centric rlation. J Prosthet J):nt 12: 464-472 1962.

35) Poswillo, D.: Jixpr.timental investigation of the rfleets of intra-articular hydrocortisone and high condylectomy on the mandibular condyle. Oral Surg 30: 161-173 1970.

36) Barbenel, J.C.: 'I'he mechanics of the temporomandibular joint-a theoretical and electromyographical study. J Oral Rehabilitation 1: 19-27 1974 .

37) Ito, I., Gibbs, C.H., et al.: Loading on the temporomandibular joints with occlusal conditions. J Prosthet Dent 56: 478-484 1986.

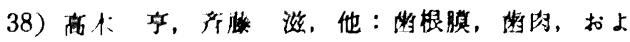

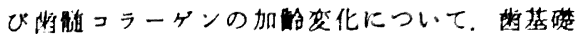
誌 17: 432-441 1975.

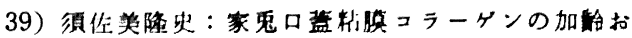

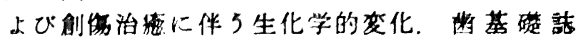
27: 64-79 1985.

40) Robins, S.P. and Bailey, A. J.: Age-related change in collagen: The identification of reducible lysinecarbohydrate condensation products. Biochem Biophys Res Commun 48: 76-84 1972.

41) Takagi, Y., Koshiba, H.,et al.: Dentinogenesis imperfecta: evidence of qualitative alteration in the organic dentin matrix. $J$ Oral Pathol 9: 201-209 1980.

42) Takagi, Y. and Veis, A.: Matrix protein difference between human normal and dentinogenesis imperfecta dentin. Veis A.: The Chemistry and Biology of Mineralized Connective Tissues. Elsevir Nors-Holland, Amsterdam, 1981, p 233-243.

43）藤井克之, 久保木芳徳, 他：ヒト骨および関節 軟骨コラーゲンの老化の研究 - cross-link とそ の precursor の娈化について一骨代謝 7: 80-87 1973.

44）大坪和則：預口腔領域に生しる結合租樴の增殖 を主体とする疾患の生化学的ならびに組樴学的 研究一コラーゲン架橋桔合および型分析につい て一。鶴見荤 13：109-126 1987.

45) Moriguchi, T. and Fujimoto, D.: Age-related changes in the content of the collagen crosslink, pyridinoline. J Biochem 84: 933-935 1978.

46）津崎まり：ウシ象牙質コラーゲンにおける非還 元性架橋一ピリジノリン含有ベプトの単離と それらの諸性店について一。 口病誌 50：4184321983.

47) Barnard, K., Light, N.D., et al.: Chemistry of the collagen cross-links. Origin and partial characterization of a putative maturre crosslink of collagen. Biochem J 244: 303-309 1987. 
48) Fujimoto, D., Hirama, M., et al.: Histidinoalanine, a new crosslink amino acid in calcified tissue collagen. Biochem Biophys Res Commun 104: 1102-1106 1982.

49) Fujimoto, D.: Aging and cross-linking in human aorta. Biochem Biophys Res Commun 109: 1264-1269 1982.

50) Marsh, M.E.: Histidinoalanine, a naturally octurring cross-link derived from phosphoserine and histidine residues in mineral-binding phosphoproteins. Biochemistry 25: 2392-2396 1986.

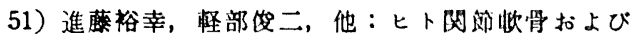
滕半月コラーゲンの加路と疾㭧に括ける生化学 的研究. 日整会誌 55：17-301981.
52) Weizngreen, H.H.: ()bservation of the atticulir disc. ()ral Surg 40: 113-121 1975.

53) Liclberg, J. and Westessun, J'.: Diagnostic accuraty of upper compartment arthroscopy of the temporomandibular joint: Correlation with pestmortem morphology. (Oral Surg 62: 618-624 1986 .

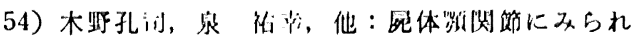

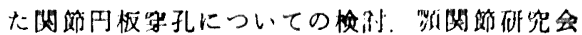
践 5: 191984 .

55) Obberg, T.: Aging of the temporomandibular disk with special relirence to the occurrence of cartilaginous cells. Odontol Tidskr 74: 122-129 1966. 